\title{
USE OF SENTINEL-2 IMAGES FOR THE DETECTION OF SANDBARS ALONG THE LOWER VISTULA
}

\author{
Klaudia Kryniecka ${ }^{\bowtie}$, Artur Magnuszewski \\ Faculty of Geography and Regional Studies, University of Warsaw, ul. Krakowskie Przedmieście 30, 00-927 Warszawa
}

\begin{abstract}
Aim of the study

The aim of this paper was to develop and test detection methods of sandbars for a selected section of the Lower Vistula (Wisła) river with the use of Sentinel-2 Level 2A optical images.

Material and methods

The analyses were performed in the QGIS (version 2.18.4) and SNAP (version 7.0) software. Both the image reprogramming and pixel value analysis were conducted in the SNAP software. QGIS was used to perform satellite data, i.e. processing, surface analysis, and their visualisation. For multispectral images, water indices were used such as: NDWI (Normalized Difference Water Index); MNDWI (Modified Normalized Difference Water Index); AWEIsh (Automated Water Extraction Index shadow); AWEInsh (Automated Water Extraction Index no shadow); LSWI (Land Surface Water Index); MLSWI (Modified Land Surface Water Index); MSI (Moisture Stress Index); SWM (Sentinel Water Mask) to separate sandbars from a water. These index methods base on a threshold value. Not all tested indices provided satisfactory results. Therefore, the layers were generated for 5 water indices.
\end{abstract}

\section{Results and conclusions}

The analyses have shown that, for the selected section of the Lower Vistula, it is possible to detect sandbars in the river channel on the basis of Sentinel-2 satellite's data. A proper selection of remote sensing index, creation of binary classification and selection of processing algorithm are important when detecting river sand bars. Every water index used produced different results. The difference may be reduced by improving the threshold value algorithm.

Keywords: Sentinel-2, sandbars, spatial analysis, water indices, NDWI, SWM

\section{INTRODUCTION}

A new way approach to determine the dynamics of sandbars movement on the Lower Vistula is the analysis of sequence of satellite images, which make it possible to determine the shape, size, and migration velocity of channel mesoforms over a particular period of time (Babiński, 1992). As part of the Copernicus Programme, the Sentinel-2A satellite was launched on
23 June 2015 by the European Space Agency (ESA). Sentinel-2A is an image recorder a platform equipped with an innovative wide-angle $(290 \mathrm{~km})$, high speed, and a multi-spectral video recorder scanner (MSI Multispectral Instrument) with 13 spectral bands. Together with the twin satellite Sentinel-2B it is a source of very useful information about land and water areas (Kurczyński, 2014). The revisit period of Sentinel-2 satellites is 5 days (Robak et al., 2016). 
The aim of this article is to develop and test sandbars detection methods for a selected section of the Lower Vistula River channel. The archival images of the Sentinel-2 were used for this study. Research problems were the optimisation of tools, and the selection of remote sensing indices used for the detection of inland and coastal waters in the images of Sentinel-2. In general, the main assumption was to discover arithmetic expression that would produce the highest contrast value between different wavelengths.

Spectral indices are math arithmetic expressions with a minimum of two wavelengths of spectral reflectance. The equations are flexible in application because they use universal terms, which do not depend on the sensors that were used. Water indices are used for the delineation of water from the background using a fixed threshold value (Acharya et al., 2020).

The most widely used water index is NDWI (Normalised Difference Water Index). The NDWI was developed by McFeeters (1996) and it uses green and near-infrared (NIR) bands to identify water surface. The author uses a zero threshold value in the research. Another important index is MNDWI (Modified Normalised Difference Water Index), which was proposed by $\mathrm{Xu}$ (2006), and which is a new version of NDWI. The researcher noted poor separation of water from urban areas. Therefore, instead of NIR band in equation created by McFeeters (1986), he used shortwave infrared (SWIR). Other indices frequently appearing in the literature are AWEIsh (Automated Water Extraction Index shadow) and AWEInsh (Automated Water Extraction Index no shadow) developed by Feyisa et al., (2004). The first was adapted to detect water in mountain environment, where shadows are problematic on multispectral images. It used green, NIR and SWIR bands. The other was adapted to detect water within urban areas, where blue, green, NIR, and SWIR bands were used in the equation. Following indices such as LSWI (Land Surface Water Index) and MLSWI (Modified Land Surface Water Index) are also used to detect water surfaces, whereas MLSWI is especially useful for detecting flood areas. This latter index was created from two indices: NDWI and LSWI by Kwak (2017), and it uses NIR and SWIR bands. Researchers often use different indices, comparing and combining them. Chandrasekar et al., (2010) compared the LSWI, which applies SWIR and
NIR bands and detects plant and soil moisture, with the vegetation index NDVI (Normalised Difference Vegetation Index), which determines plant condition. Li et al., (2014) performed a similar exploration. Sriwongsitanon et al., (2015) in their study compared NDII (Normalised Difference Infrared Index) with conceptual hydrological model, and Niedzielko et al., (2012) compared NDII and MSI (Moisture Stress Index) with field studies. The last index used in this study is SWM (Sentinel Water Mask), dedicated to detecting water from Sentinel-2 images. It has been developed by Robak et al., (2016).

\section{STUDY AREA}

The Vistula River is the major river in Poland, $1022 \mathrm{~km}$ long. Its mean annual discharge is $1080 \mathrm{~m}^{3} \cdot \mathrm{s}^{-1}$ (Pociask-Karteczka, 2017). It flows through Poland, having its sources in the Beskidy Mountains, and its mouth at the Bay of Gdansk in the Baltic proper. A fragment of the lower Vistula section was selected for analysis km $812-878$ (see: Fig. 1).

The lower Vistula riverbed is shaped by natural and anthropogenic factors (Łajczak et al., 2006; Kałmykow-Piwińska and Falkowski, 2012). The hydrological conditions expressed by the volume of flow and sediment transport of bed load have the greatest impact on the dynamics of the resulting channel forms (Babiński, 1992; Pieron et al., 2013; Bogucka-Szymalska, 2010; Nones et al., 2018; Zhang et al., 2020). In the case of the lower Vistula, its hydrotechnical regulation in the form of the river training structures is also important (Babiński, 1999). On the lower reach of the river, just below barrage in Włocławek, an accelerated deep erosion is observed, while in the further part of the course, an accelerated accumulation of alluvial material occurs (Pociask-Karteczka, 2017; Babiński, 2009). The course of sediment transport in the regulated section of the lower Vistula determines the shipping conditions and has a significant impact on flood safety (Kurczyński and Bakuła, 2016; Babiński and Habel, 2017). River training works carried out in the lower part of the Vistula at the end of the nineteenth century reduced the width of the riverbed by almost half and straightened its course (Babiński, 1992). The regulations of the lower Vistula riverbed were not car- 


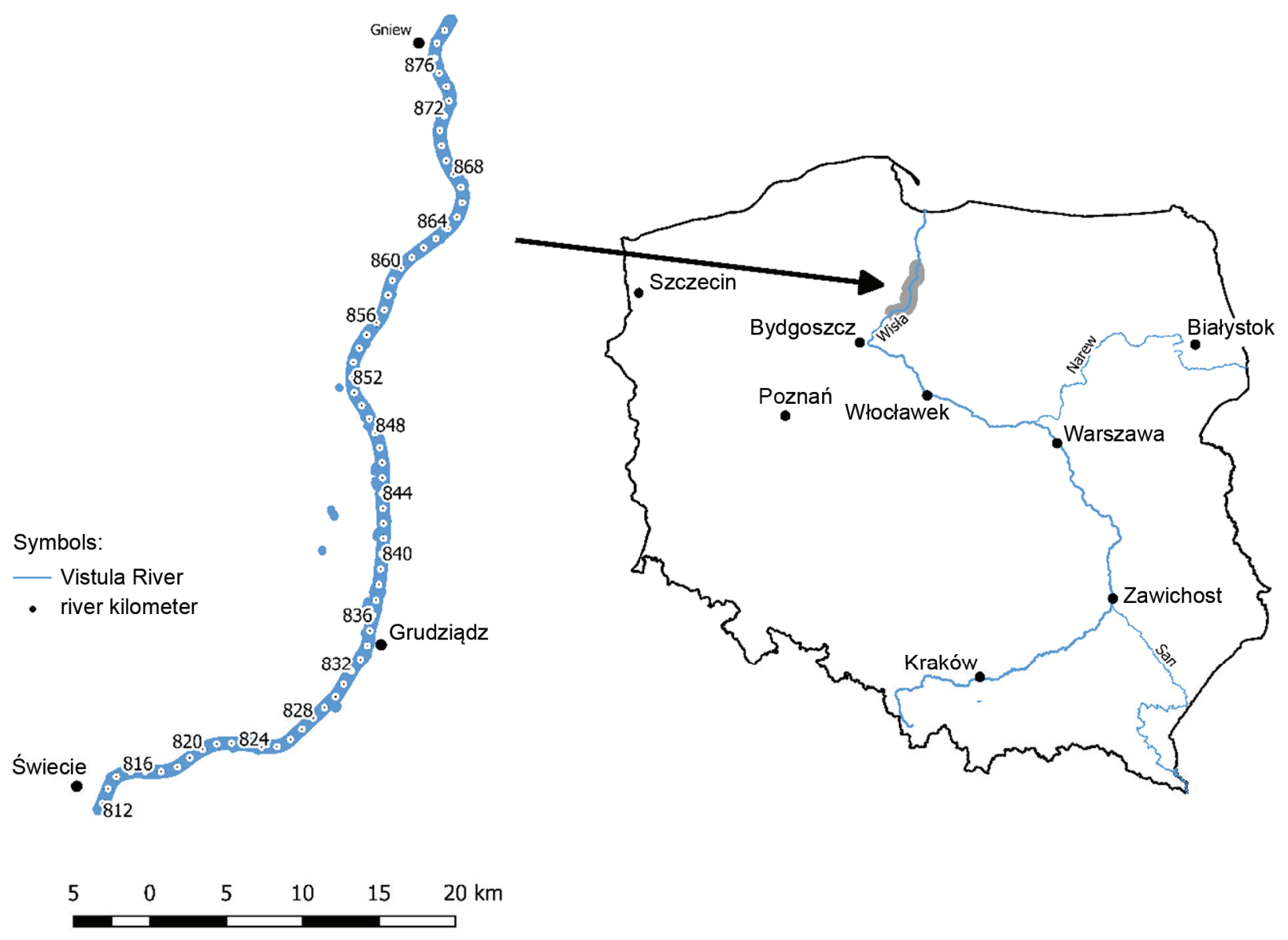

Fig. 1. Location of the study area

Source: own study.

ried out systematically. Narrowing of the riverbed by spurs, which were supposed to limit the amount of sediment load and the accumulation of it in areas between spurs, did not produce the desired outcome (Majewski, 2008). Due to the significant human interference, the Vistula riverbed has lost many of the typical features of natural rivers (Babiński, 1989).

The riverbed forms constitute an important element of the morphology of the Vistula riverbed. They are addressed in the research of many authors who characterized the dynamics of their displacement (Babiński, 1992; Pieron et al., 2013). Large volume of sediments transport in the lower Vistula River promotes conditions for the development of river channel mesoforms. According to Ahmari and da Silva (2011), the type of channel mesoforms in the river channel is controlled by the two dimensionless parameteres of $\mathrm{B} / \mathrm{h}_{\mathrm{m}}$ (channel width $[\mathrm{m}]$ and average depth [m]) and $\mathrm{h}_{\mathrm{m}} / \mathrm{D}$ (channel depth [m] and representative sediment grain size $[\mathrm{m}]$ ). The hydraulic characteristics of average discharge of the lower Vistula River were calculated by Łajczak (1991) from hydrometric measurements results published in hydrological yearbooks of Poland (see: Table 1).

Representative grain size of the bedload in the studied section was obtained by the sieve analysis of the sediments samples taken from the sandbars in the river reach of $\mathrm{km} 842-867$, and it equals $\mathrm{D}=0.5 \mathrm{~mm}$ (Materiał... 1954)

To characterize the regime of the Vistula river channel processes, we calculated two dimensionless indexes $B / h_{m}=120$ and $h_{m} / D=6300$, which provided 
Table 1. Average values of lower Vistula river channel cross section characteristics calculated from the data of hydrometric measurements results after Łajczak (1991), modified by the author

\begin{tabular}{ccccc}
\hline $\begin{array}{c}\text { Vistula River } \\
\text { regulated } \\
\begin{array}{c}\text { cross section } \\
\text { characteristics }\end{array}\end{array}$ & $\begin{array}{c}\text { Discharge } \\
\text { at Toruń } \\
\text { gauge }\left[\mathrm{m}^{3} \cdot \mathrm{s}^{-1}\right]\end{array}$ & $\begin{array}{c}\text { Channel } \\
\text { width }\end{array}$ & $\begin{array}{c}\text { Average } \\
\text { depth in } \\
\text { the cross } \\
\text { section } \\
h_{m}[\mathrm{~m}]\end{array}$ & $\begin{array}{c}\text { Average } \\
\text { velocity in } \\
\text { the cross } \\
\text { section } \\
v_{m}\left[\mathrm{~m} \cdot \mathrm{s}^{-1}\right]\end{array}$ \\
\hline $\begin{array}{c}\text { Average mean } \\
\text { flow }\end{array}$ & 992 & 380 & 3.17 & 0.89 \\
\hline
\end{tabular}

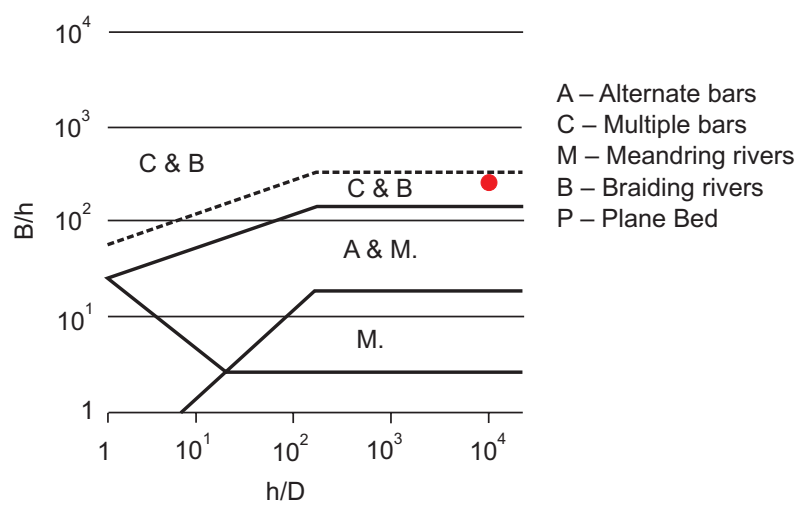

Fig. 2. Hydraulic parameters of the lower Vistula River channel shown in the graph of alternate and multiple bars development conditions $\left(\mathrm{B} / \mathrm{h}_{\mathrm{m}} ; \mathrm{h}_{\mathrm{m}} / \mathrm{D}\right)-$ after Ahmari and Silva (2011), modified by the author. The red dot points to where lower Vistula belongs the coordinates of the point shown in the graph below. Figure 2 shows domains of different channel forms in natural rivers and laboratory flumes (Ahmari and Silva, 2011). The average flow discharge in the lower Vistula river creates the conditions for the formation of mesoforms located in the transition area between multiply bars and alternate bars.

\section{MATERIAL AND METHODS}

The analyses were performed in QGIS (version 2.18.4) and SNAP (version 7.0) software. Both the image resampling and pixel values analysis were conducted in the SNAP. QGIS was used to calculate sand bars area and to develop their visualisation. The further part of the text presents IT tools and commands available in QGIS and SNAP, which were used in the research work.

A detection of the lower Vistula riverbed forms, using Sentinel-2 satellite imagery, was performed according to the following diagram (see: Fig. 3.)

In the first stage, preprocessed by Sen2Cor processor, after atmospheric correction, Sentinel-2 Level 2A satellite images were obtained from the Sentinel Scientific Data Hub dated 24/08/2019. When choosing the day of the imaging, the low water level of the Vistula River was taken into account, which is a condition for the emergence of sandbars.

For the purpose of the analysis, all channels were cut to the geographical range of the examined area, (the

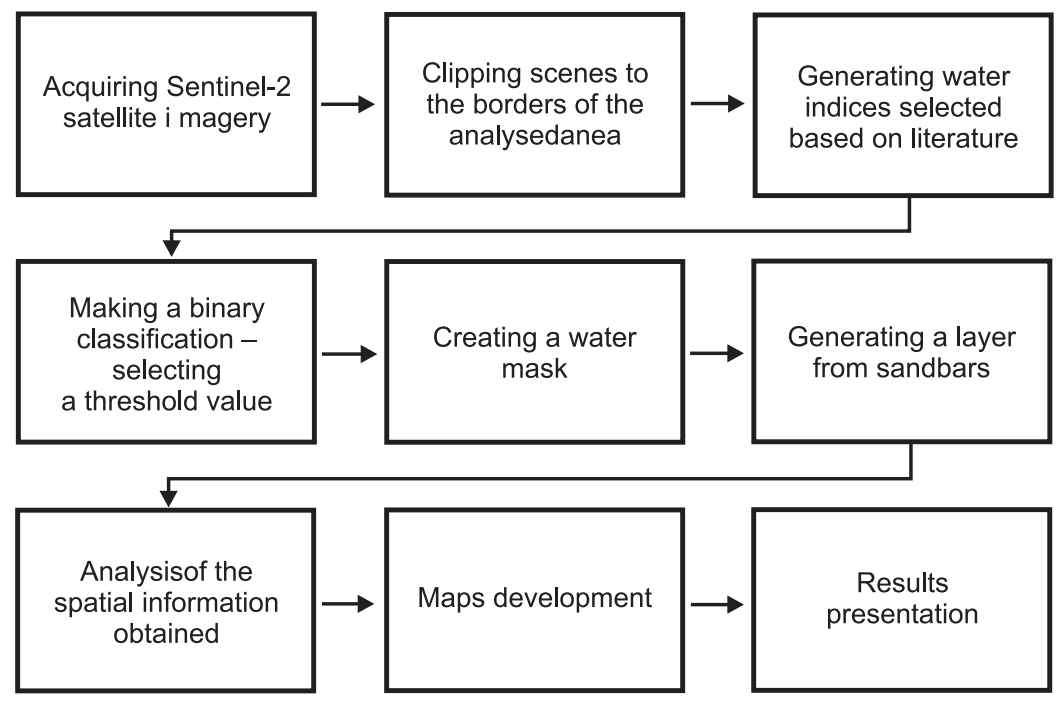

Fig. 3. Diagram of the procedure 
whole study area extends between $18^{\circ} 23^{\prime}$ and $19^{\circ} 1^{\prime} \mathrm{E}$ and $53^{\circ} 22^{\prime}$ and $53^{\circ} 23^{\prime} \mathrm{N}$ ). This area was selected on the basis of visual analysis, the criterion being the existence an abundance of sandbars on a straight reach of the river channel.

The images were clipped using Python script. The clipping was necessary because the Sentinel-2 scene had an excessive size of $100 \times 100 \mathrm{~km}$.

In the next step, in SNAP, a resampling was done on individual channels from a resolution of $10 \mathrm{~m}$ to 20 $\mathrm{m}$ so that it was possible to calculate and generate the water indices.

Next, using the Raster Calculator tool in QGIS, the following water indices were calculated by using formulas (1-8), and results in the form of images were generated (see: Fig. 4):

$$
\begin{gathered}
N D W I=\frac{G R E E N-N I R}{G R E E N+N I R} \\
N D I I=\frac{N I R-S W I R}{N I R+S W I R} \\
M N D W I=\frac{G R E E N-S W I R}{G R E E N+S W I R} \\
A W E I n S h=4 \times(G R E E N-S W I R 1)- \\
-(0.25 \times N I R+2.75 \times S W I R 2) \\
A W E I S h=B L U E+2.5 \times G R E E N- \\
-1.5 \times(N I R+S W I R 1)-0.25 \times S W I R 2 \\
L S W I=\frac{N I R-S W I R}{N I R+S W I R} \\
M L S W I=\frac{1-N I R-S W I R}{1-N I R+S W I R} \\
S W M=\frac{B L U E+G R E E N}{N I R+S W I R 1}
\end{gathered}
$$

where: BLUE is Band 2 with a wavelength of $490 \mathrm{~nm}$; GREEN is Band 3 with a wavelength of $560 \mathrm{~nm}$; RED is Band 4 with a wavelength of $665 \mathrm{~nm}$; NIR is Band 8 with a wavelength of $842 \mathrm{~nm}$; SWIR1 is Band 11 with a wavelength of $1610 \mathrm{~nm}$; SWIR2 is Band 12 with a wavelength of $2190 \mathrm{~nm}$.

The next step was the calculation of a water mask from the generated water indices. In order to process a binary classification of the images, the Raster Calculator was used. The procedure consisted of matching pixels into two classes. It was assumed that pixels with a similar spectral reflection correspond to the same objects (Golenia et al., 2016). The first class was water (1-TRUE), while the second class was everything but not water (0-FALSE). Not all indices produced satisfactory results in the initial visual analysis and the detection of water was in some cases not possible, therefore NDII, LWSI and MLSW were excluded from our further analysis. The threshold value (t) for each of the indices was set manually, based on the histogram (see: Fig. 5) (Robak et al., 2016; Du et al., 2015). This is the minimum value at the graph (Otsu, 1979). The threshold values selected for each of the analysed indices are presented in Table 2.

Objects that represented the Vistula were selected using the "selection" tool and a new layer was created on which the objects were joined using the "dissolve" tool. The resulting layer was cleaned of the river sandbars objects using the "remove rings" tool.

In the next step, the "sum" (geometrical sum) tool was used to add the two layers: layer 1 - cleared of objects and layer 2 - not filtered. Then, using the "select" tool, a new layer with sandbars was created.

For comparison, Sentinel-2 Level 1C images were also analysed as described by Robak et al., (2016). The study showed that the contrast between water and land is better in Level 1C data than Level 2A. However, in the quoted study, the aim was to receive a good quality

Table 2. Threshold values selected for the analysed water indices.

\begin{tabular}{cc}
\hline Water index & Threshold value $(\mathrm{t})$ \\
\hline NDWI & 0.054 \\
\hline MNDWI & -0.086 \\
\hline AWEIsh & 214.268 \\
\hline AWEInsh & -146.432 \\
\hline SWM & 0.957 \\
\hline
\end{tabular}



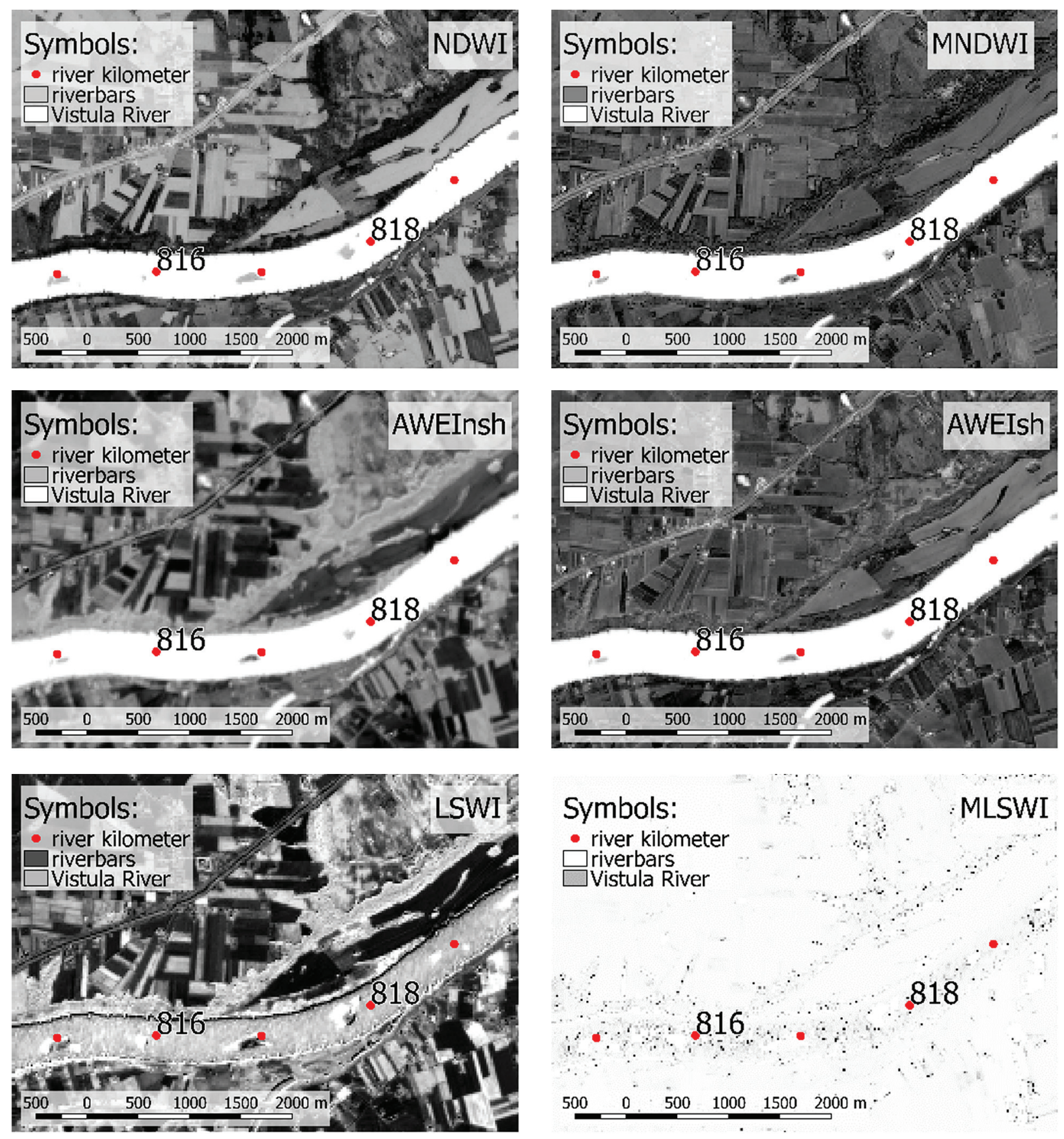

\section{Symbols:}

river kilometer
$\square$ riverbars

$\square$ Vistula River
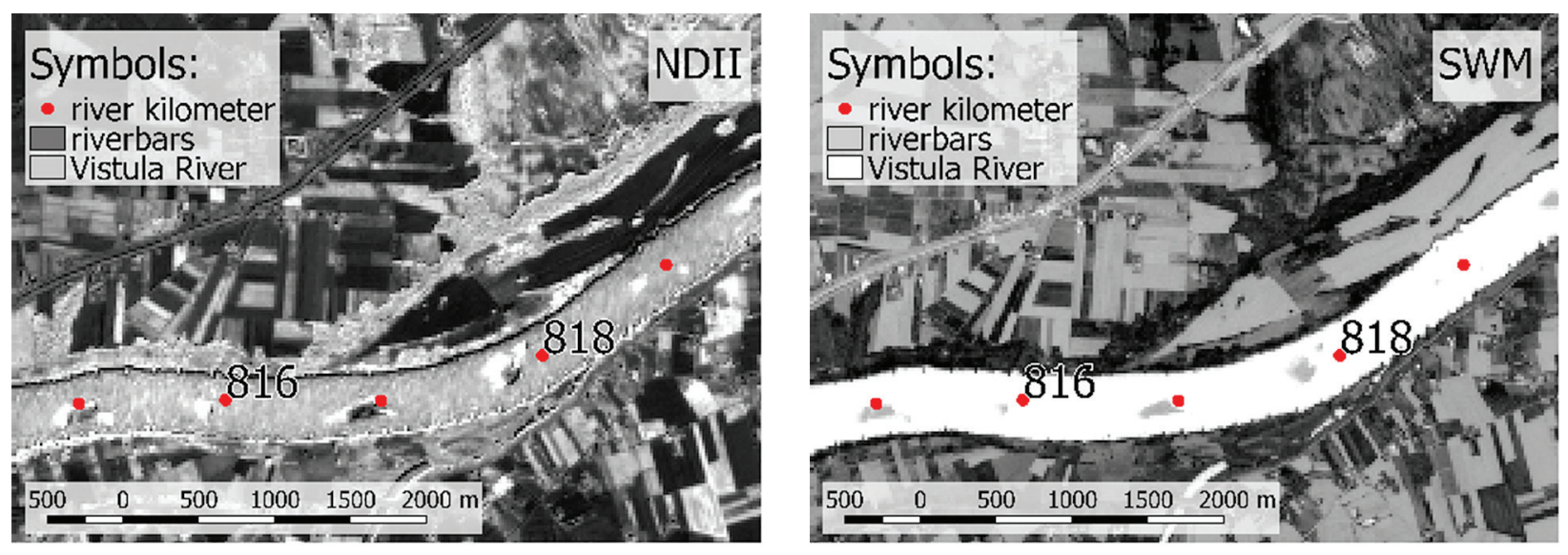

Fig. 4. Lower Vistula River section at km 815-820, selected for detailed view and comparison between different water indices

Source: own study. 

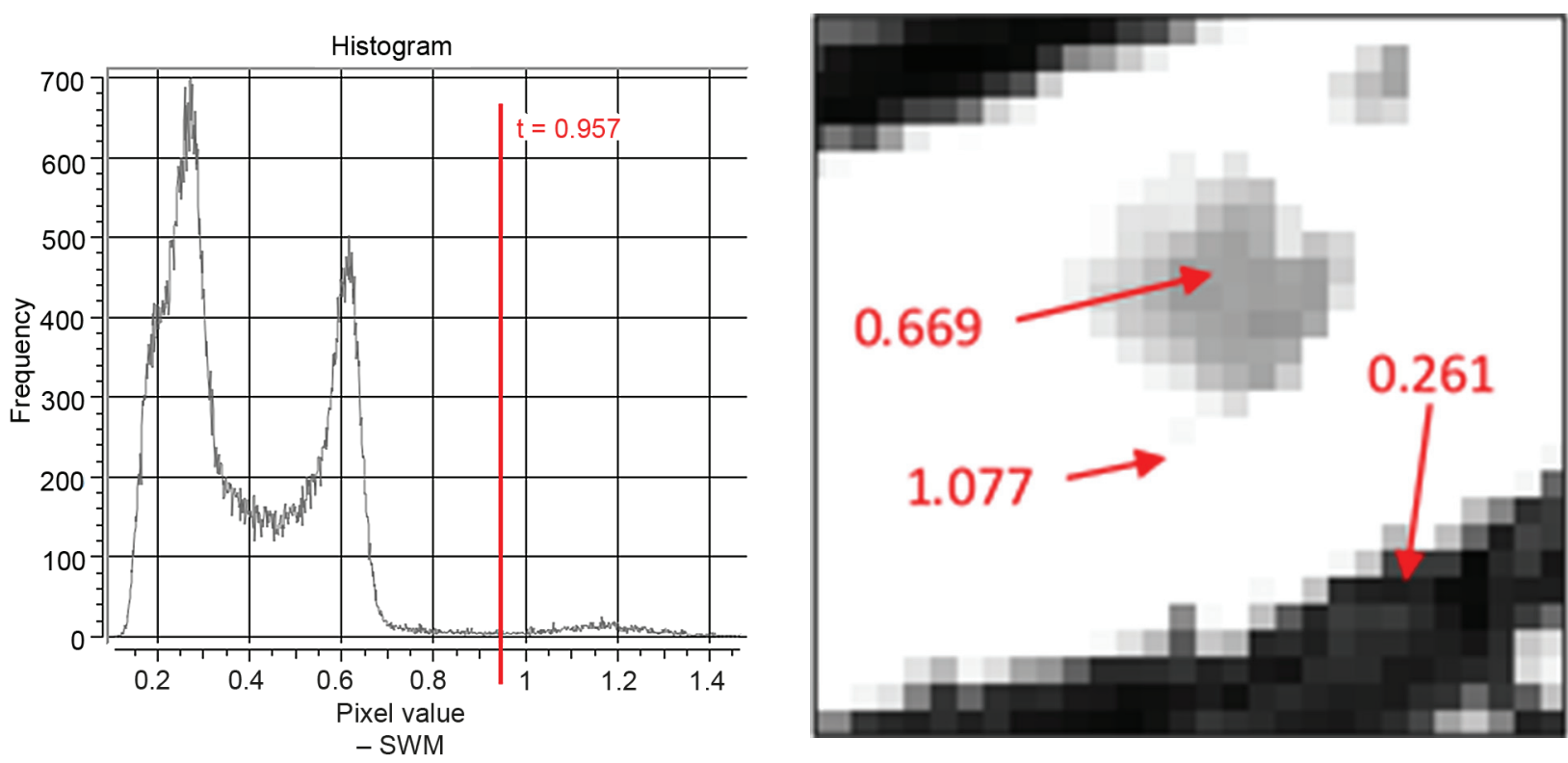

Fig. 5. A sample histogram with the threshold value (t) for the SWM index (left); Zoom to one of the channel forms with the information about the pixel value (right)

Source: own study.

visual assessment of the usefulness of water indices for the detection of sandbars in the river channel. In this study, an image of Level 2A was used for visual comparison of the RGB composition with the calculated water indices.

\section{RESULTS AND DISCUSSION}

As the result of the performed processing, vector data visualizing sandbars along the analysed fragment of the lower Vistula were obtained based on the optical satellite data and water indices (see: Fig. 6). For a closer look of the water indices results, a subsection of the Vistula River was selected at km 815-820. The results of the analysis (the number of detected sandbars and their total area) obtained using various water indices were given in Table 2.

The examination of water indices showed which of them are best suited for the precise detection of sandbars. The analysis took into account five indices: NDWI, MNDWI, AWEIsh, AWEInsh, and SWM. The total area of the channel forms is the largest in the case of the SWM index $\left(0.58 \mathrm{~km}^{2}\right)$, and the smallest for AWEInsh $\left(0.20 \mathrm{~km}^{2}\right)$.
Table 3. Lower Vistula River section at km 812-878. Generated sandbar layers area based on water indices

\begin{tabular}{ccc}
\hline Water index & Number of sandbars & Area $\left[\mathrm{km}^{2}\right]$ \\
\hline NDWI & 55 & 0.29 \\
\hline MNDWI & 35 & 0.28 \\
\hline AWEIsh & 34 & 0.35 \\
\hline AWEInsh & 33 & 0.20 \\
\hline SWM & 82 & 0.58 \\
\hline
\end{tabular}

The examination carried out in this study has shown that it is possible to detect the sandbars in the river on the basis of Sentinel-2 satellite data. Correct selection of a remote sensing index, creation of the binary classification, and selection of the processing algorithm are important when detecting river sandbars.

The riverbed of the analysed section of the lower Vistula is characterised by the intensive transport of alluvial material, hence these islands are constantly being supplied with new matter. In addition, these sandbars are being shifted (Babiński, 1999). The analysis of channel forms may lead to the assessment of hydrodynamic conditions of the river (Babiński, 
An example would be the research conducted by Burshtyńska et al., (2017), who performed a longterm analysis of changes in the shape of the riverbed of a hundred-kilometer section of the Dniester River. The author used topographic and soil maps as well as Landsat and Sentinel-2 satellite data for her research. To extract the riverbed from optical images, they used the NDWI. As a result of the analyses, a map of changes was created, and a high correlation of sedimentation processes with the increase in the number and surface of sandbars was demonstrated.

Similar procedure was followed by Cao (2020), who based their work on a full time series of Landsat images during 1985-2017. Using MNDWI, they developed a map of changes in the coastlines and in the Zhoushan Archipelago (China).

Sentinel-2 optical images, Sentinel-1 SAR radar images, and camera images were used to track changes in the sandbar on the Po River in Italy (Papa et al., 2020). The purpose of the research was to test the possibilities offered by various data sources in shoreline observation.

Baki and Gan (2012) in their research used photos from the Landsat MSS and TM missions to examine the dynamics of channel forms over a period of 30 years. In their work, they analysed the dynamics of shifts in riverbanks and islands.

Similarly, Pekel et al., (2016) have raised the issue of mapping global surface water and its long-term changes over a period of 30 years. The data he uses in his work comes from Landsat. Researchers used a procedural sequential decision tree to detect water.

Water detection on the Sentinel-2 satellite images is a research problem in the work of Pluto-Kossakowska et al., (2018). In their research, they checked the possibilities of using Sentinel-2 images, for the extraction of "blue infrastructure" - i.e. water. For this purpose, they used the NIR band and applied the thresholding method.

\section{CONCLUSION}

Detection of sandbars in the lower Vistula using the optical data of Sentinel-2 is a new approach and should be explored further. As analysed in this paper, the best results in the remote detection of sandbars are achieved by applying the SWM water index, developed by Ro- bak et al., (2016). This index renders the highest degree of precision in detecting river islands due to the highest contrast and enhancing water spectral signal.

The data processing methodology was partly inspired by the work of Zhang et al., (2020). Several valuable comments were also drawn from the work of Robak et al., (2016), in which the water indices were tested to create a water mask in the shortest possible time for crisis management.

The Sentinel-2 data were developed for the purpose of monitoring land. Due to their characteristics, they provide many opportunities for research in the field of hydrology and water management, such as sandbars' detection and monitoring changes in river channels. This paper presents the first set of the biggest part of the research project. The presented methods using the Sentinel-2 data will be continued and extended in the doctoral thesis.

\section{REFERENCES}

Acharya, T. D., Subedi, A., Lee, D. H. (2018). Evaluation of Water Indices for Surface Water Extraction in a Landsat 8 Scene of Nepal. Sensors, 18(8), 2580. DOI: 10.3390/ s18082580

Ahmari, H., Da Silva, A.M.F. (2011). Regions of bars, meandering and braiding in da Silva and Yalin's plan, Journal of Hydraulic Research, 49:6, 718-727, DOI: 10.1080/00221686.2011.614518.

Babiński, Z. (1989). The Changes of Hydromorphological Conditions of the Lower Vistula Channel Caused by Human Impact, X Vedecka Konference, Hydraulika a Hydrotechnika, Vysoke Uceni Technicke, Brno, 62-67.

Babiński, Z. (1992). Współczesne procesy korytowe dolnej Wisły (Contemporary river bed processes of the lower Vistula river), Prace Geograficzne, 157, Warszawa.

Babiński, Z. (1999). Zmiany transportu rumowiska klastycznego dolnej Wisły w wyniku prac hydrotechnicznych (Changes of clastic rock-debris transportation in the lower Vistula river as a result of water regulation works), Acta Universitatis Nicolai Copernici, Geografia XXIX, Nauki Matematyczno-Przyrodnicze, Toruń, 103, 327-335.

Babiński, Z. (2009). Dynamika strefy akumulacyjnej poniżej czoła odcinka o wymuszonej erozji wgłębnej Zbiornika Włocławskiego. Prace Geograficzne, 157.

Babiński, Z., Habel, M. (2017). Wykorzystanie i zagrożenia rzek i wód rzecznych. Hydrologia Polski, 201-208. 
Bogucka-Szymalska, M. (2010). Changes in morphology of selected segments of the Vistula river bed. Miscellanea Geographica, 14, 193-202, DOI: 10.2478/ mgrsd-2010-0018.

Baki, A.B.M., Gan, T.Y. (2012). Riverbank migration and island dynamics of the braided Jamuna River of the Ganges-Brahmaputra basin using multi-temporal Landsat images. Quaternary International 263, 148-161. https:// doi.org/10.1016/j.quaint.2012.03.016.

Burshtynska, K., Malochkin, M., Tretyak, S., Zayats, J. (2017). Monitoring of reverbed of river Dniestr using GIS technologies. Archiwum Fotogrametrii, Kartografii i Teledetekcji, 29, 25-36. DOI: 10.14681/afkit.2017.002.

Cao, W., Zhou, Y., Li, R., Li, X. (2020). Mapping changes in coastlines and tidal flats in developing islands using the full time series of Landsat images. Remote Sensing of Environment 239, 111665. https://doi.org/10.1016/j. rse.2020.111665.

Chandrasekar, K., Sesha, Sai, M. V. R, Roy, P. S., Dwevedi, R. S. (2010). LandSurface Water Index (LSWI) response to rainfall and NDVI using the MODIS Vegetation Index product,International Journal of Remote Sensing, 31:15, 3987-4005, DOI: 10.1080/01431160802575653.

Du, Y., Zhang, Y., Ling, F., Wang, Q., Li, W., Li, X. (2015). Water Bodies' Mapping from Sentinel-2 Imagery with Modified Normalized Difference Water Index at 10-m Spatial Resolution Produced by Sharpening the SWIR Band, Remote Sensing, 8, 354.

Feyisa, G.L., Meilby, H., Fensholt, R., Proud, S.R, (2014). Automated Water Extraction Index: A new technique for surface water mapping using Landsat imagery, Remote Sensing of Environment, 140, 23-35 C.

Golenia, M., Gurdak, R., Jarocińska, A., Mierczyk, M., Ochtyra, A., Zagajewski, B. (2016). Zastosowanie zobrazowań satelitarnych Landsat do detekcji zmian obszarów zurbanizowanych. (Application of Landsat images in urban change detection). In: Buławka N., Chyla J. M., Lechnio J., Misiewicz K., Stępień M. (eds.), Forum GIS UW. GIS na Uniwersytecie Warszawskim. Forum użytkowników licencji edukacyjnej SITE oprogramowania ArcGIS na Uniwersytecie Warszawskim. Conference proceedings. II/III, 91-101, December 2016.

Kałmykow-Piwińska, A., Falkowski, T., (2012). Assessment of the channel morphologic stability in the base of archival cartographic and photogrammetric data in GIS environment, Scientific Review - Engineering and Environmental Sciences, 58, 251-262.

Kuenzer, C., Heimhuber, V., Huth, J., Dech, S. (2019). Remote Sensing for the Quantification of Land Surface
Dynamics in Large River Delta Regions - A Review. Remote Sens., 11, 1985.

Kurczyński, Z., Bakuła, K. (2016). SAFEDAM - zaawansowane technologie wspomagające przeciwdziałanie zagrożeniom związanym z powodziami. Archiwum Fotogrametrii, Kartografii i Teledetekcji, 28, 39-52. DOI: 10.14681/afkit.2016.003.

Kurczyński, Z. (2014). Fotogrametria. Warszawa: Wydawnictwo Naukowe PWN.

Kwak, Young-Joo. (2017). "Nationwide Flood Monitoring for Disaster Risk Reduction Using Multiple Satellite Data.” ISPRS Int. J. Geo-Inf. 6, 7, 203.

Langhammer, J., Bernsteinová, J., Mǐrijovský, J., (2017). Building a High-Precision 2D Hydrodynamic Flood Model Using UAV Photogrammetry and Sensor Network Monitoring. Water, 9, 861.

Li P, Jiang L, Feng Z. (2014). Cross-Comparison of Vegetation Indices Derived from Landsat-7 Enhanced Thematic Mapper Plus (ETM+) and Landsat-8 Operational Land Imager (OLI) Sensors. Remote Sensing. 6(1), 310-329.

Łajczak, A., (1991). Zróżnicowanie prędkości przepływu w profilu podłużnym Wisły. Wiadomości Instytutu Meteorologii i Gospodarki Wodnej, 14, 1-4, 55-67.

Łajczak, A., Plit, J., Soja, R., Starkel, L., Warowna, J. (2006). Changes of the Vistula river channel and floodplain in the last 200 years. Geographia Polonica 79, 65-87.

Majewski, W. (2008). Zintegrowane zarządzanie gospodarką wodną na obszarze dolnej Wisły. Rewitalizacja drogi wodnej Wisła-Odra szansą dla gospodarki regionu, Przyroda i Turystyka Rejonu Pomorza i Kujaw. s. 20.

Materiał wleczony i unoszony w korycie Wisły, (1954). Prace Państwowego Instytutu Hydrologiczno-Meteorologicznego, 33.

McFeeters, S. K. (1996) The use of the Normalized Difference Water Index (NDWI) in the delineation of open water features, International Journal of Remote Sensing, 17, 7, 1425-1432, DOI: 10.1080/01431169608948714.

Niedzielko, J., Szepietowska, M., Boral, B., Milczarek, M., Pokrzywnicka, M., Łach, G., Kaźmierczak, M., Jarocińska, A. (2012). Analiza zależności między zawartością wody w roślinach zmierzoną w terenie a teledetekcyjnymi wskaźnikami roślinności, Teledetekcja Środowiska, 47, 43-58.

Nones, M., Archetti, R., Guerrero, M. (2018). Time-Lapse Photography of the Edge-of-Water Line Displacements of a Sandbar as a Proxy of Riverine Morphodynamics. Water, 10, 617.

Otsu, N. (1979). A Threshold Selection Method from Gray-Level Histograms in IEEE Transactions on Sys- 
tems, Man, and Cybernetics, 9, 1, 62-66. DOI: 10.1109/ TSMC.1979.4310076.

Papa, M., Nones, M., Cavallo, C., Gargiulo, M., Ruello, G. (2020). Data-fusion of satellite and ground sensors for river hydro-morphodynamics monitoring. 10.5194/ egusphere-egu2020-20381.

Pekel, J.-F., Cottam, A., Gorelick, N., Belward, A.S. (2016). High-resolution mapping of global surface water and its long-term changes. Nature, 540, 418-422. https://doi. org/10.1038/nature20584.

Pieron, Ł., Hojan, M., Habel, M. (2013). Charakterystyka łach korytowych uregulowanego odcinka dolnej Wisły. Journal of Health Sciences, 3(14), 114-123.

Pluto-Kossakowska, J., Władyka, M., Tulkowska, W. (2018). Ocena obrazowych danych teledetekcyjnych do identyfikacji obiektów w zielonej i błękitnej infrastrukturze. Teledetekcja Środowiska, 13-27.

Pociask-Karteczka, J. (2017). Położenie hydrograficzne Polski na tle Europy. Hydrologia Polski, 15-21.

Robak, A., Gadawska, A., Milczarek, M., Lewiński, S. (2016). The detection of water on Sentinel-2 imag- ery based on water indices. Teledetekcja Środowiska, 59-72.

Scorpio, V., Zen, S., Bertoldi, W., Surian N., Mastronunzio M., Dai Prà E., Zolezzi G., Comiti F., (2018). Channelization of a large Alpine river: What is left of its original morphodynamics? Earth Surf. Process. Landf., 43, 1044-1062.

Sriwongsitanon, N., Gao, H., Savenije, H., Maekan, E., Saengsawang, S., Thianpopirug, S. (2015). The Normalized Difference Infrared Index (NDII) as a proxy for soil moisture storage in hydrological modelling. Hydrol. Earth Syst. Sci. Discuss.,12, 8419-8457.

$\mathrm{Xu}$, H. (2006). Modification of Normalized Difference Water Index (NDWI) to Enhance Open Water Features in Remotely Sensed Imagery, International Journal of Remote Sensing, 27(14), 3025-3033.

Zhang, Y., Cai, X., Yang, C., Li, E., Song, X., Ban, X. (2020). Long-Term (1986-2018) Evolution of Channel Bars in Response to Combined Effects of Cascade Reservoirs in the Middle Reaches of the Hanjiang River. Water, 12, 136.

\section{WYKORZYSTANIE ZDJĘĆ SENTINEL-2 DO DETEKCII WYSP RZECZNYCH NA DOLNEJ WIŚLE}

\section{ABSTRAKT}

\section{Cel pracy}

Opracowanie i przetestowanie metody detekcji form korytowych na wybranym odcinku dolnej Wisły. Do przeprowadzenia badań wykorzystano archiwalne, powszechnie dostępne obrazy satelitarne Sentinel-2. Problemem badawczym jest optymalizacja narzędzi, danych retrospektywnych oraz wybór stosownych istniejących wskaźników teledetekcyjnych służących do wykrywania wód śródlądowych i przybrzeżnych na obrazach satelitarnych Sentinel-2.

\section{Materiat i metody}

Analizy przeprowadzono w oprogramowaniu QGIS (wersja 2.18.4) oraz SNAP (wersja 7.0). W oprogramowaniu SNAP wykonano przepróbkowanie obrazów oraz analizę wartości pikseli. Natomiast w oprogramowaniu QGIS wykonano działania należące do reszty etapów pracy z danymi satelitarnymi, tj. przetworzeń, analizy powierzchni oraz ich wizualizacji.

\section{Wyniki i wnioski}

Wykonane w niniejszej pracy badania w biegu analizowanego odcinka dolnej Wisły wykazały, ze możliwe jest wykrycie form korytowych w rzece na podstawie danych satelitarnych Sentinel-2. Duże znaczenie przy detekcji wysp rzecznych ma odpowiedni dobór wskaźnika teledetekcyjnego, utworzenie binarnej klasyfikacji oraz dobór algorytmu przetworzeń.

Słowa kluczowe: Sentinel-2, formy korytowe, wodne wskaźniki teledetekcyjne, NDWI, SWM 